\title{
Poemas grafados na cidade: espaços possíveis na obra do Coletivo Transverso
}

Larissa Alberti Ramos de Freitas; Programa de Pós-Graduação em Estudos de Linguagens, Centro de Educação Tecnológica de Minas Gerais, Belo Horizonte; <larissalberti@yahoo.com.br>.

\section{Resumo}

O presente trabalho procura investigar o lugar da poesia na paisagem urbana a partir da análise de poemas de rua construídos pelo Coletivo Transverso. Formado pelo poeta Cauê Novaes, pela poetiza e atriz Patrícia Del Rey e pela artista plástica Patrícia Bagniewski, o Coletivo atua desde 2011 em grandes cidades brasileiras pesquisando e desenvolvendo intervenções urbanas com a palavra, utilizando técnicas de stencil, grafite e sticker com a finalidade de refletir sobre as múltiplas possibilidades de socialização e construção de identidade das cidades contemporâneas. Esse estudo analisa trabalhos do coletivo com a palavra poética no intuito de identificar as características do poema quando posto em contato com o ambiente urbano. Busca-se refletir também a respeito da função lúdica da linguagem poética diante dos espaços da racionalidade técnica que compõem o horizonte das cidades contemporâneas, ao se considerar a função poética como propulsora de pinturas de novas cidades, cidades estas permeadas pelo afeto, pela troca de experiências e pelo encontro.

Palavras chave: cidade, poesia, arte urbana, literatura, racionalidade técnica, espaço.

Cidades: espaço da racionalidade e espaço da criatividade

A cidade de Sofrônia é composta de duas meias cidades. Na primeira, encontra-se a grande montanha russa de ladeiras vertiginosas, o carrossel de raios formados por correntes, a roda-gigante com cabinas giratórias, o globo da morte com motociclistas de cabeça para baixo, a cúpula do circo com os trapézios amarrados no meio. A segunda meia cidade é de pedra e mármore e cimento, com o banco, as fábricas, os palácios, o matadouro, a escola e todo o resto. Uma das meias cidades é fixa, a outra é provisória e, quando termina sua temporada, é desparafusada, desmontada e levada embora, transferida para os terrenos baldios de outra meia cidade (Calvino,1990: 61).

Espaços da racionalidade técnica. Espaços-coisa. Espaçosprótese da natureza. Seriam esses os espaços que compõem o 
horizonte das cidades contemporâneas? Haveria possibilidade de criarmos nos grandes centros urbanos, onde reina a lógica da racionalidade técnica, espaços-troca, espaços-afeto, espaços lúdicos? Marco Polo, em As cidades Invisíveis (Calvino,1990) descreve ao imperador chinês Kublai Khan, as peculiaridades dos territórios pertencentes ao império. Dentre as diversas cidades que compõem o extenso espaço até então invisível aos olhos do imperador está Sofrônia, cidade composta de duas metades. A cidade e o seu duplo constituem Sofrônia, nela, meias-cidades convivem por um tempo em um mesmo território. Sofrônia abriga a contradição de ser ao mesmo tempo um espaço de ludicidade e um espaço de racionalidade, nela as cores e o cinza se fundem, o mármore dos palácios e o cimento dos bancos convivem com as rodas gigantes e suas cabinas giratórias, com a cúpula do circo e seus trapézios amarrados no meio.

No vasto império ${ }^{1}$ da contemporaneidade, multiplica-se a imagem de Sofrônia. Em um tempo em que observa-se um amplo processo de racionalização capaz de atingir a economia, a cultura, as relações interpessoais, os comportamentos individuais, o meio geográfico, parece-nos possível enxergarmos também no seio das cidades vestígios perdidos da primeira metade de Sofrônia.

Esses vestígios, metaforizados no texto de Calvino (1990), por meio de elementos típicos do imaginário lúdico, como as rodasgigantes e a lona do circo, caracterizam uma oposição à era da racionalidade técnica e, consequentemente, ao espaço racional, que, na busca pela superação em relação ao ambiente natural, funciona como um "laboratório ideal" onde a lógica da técnica é imposta e impera de modo automático e artificial. O espaço é visto, então, como uma máquina meramente funcional e que atua cada vez mais como uma

${ }^{1} \mathrm{O}$ termo império aqui é utilizado com base nos estudos de Michael Hardt e Antonio Negri, na obra Multidão Guerra e democracia na era do Império (2004). 
prótese "perfeita" dos elementos da natureza. Todavia, há zonas das cidades em que essa racionalidade não se dá de maneira hegemônica, podendo existir em menor ou maior escala ou mesmo não existir. Como afirma Milton Santos (2002), diante da racionalidade dominante, pode-se falar de irracionalidade, ou contra-racionalidade por parte dos atores não beneficiados. As contra-racionalidades, segundo o autor irromperiam da experiência de escassez a qual estes atores são submetidos diariamente, e, localizam-se

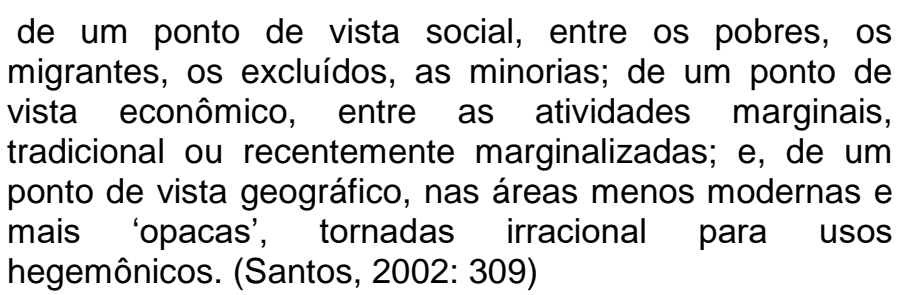

Também para Pelbart (2003), ao mesmo tempo em que o império contemporâneo, a partir da ascensão da mídia e da indústria da propaganda, exerce um controle das subjetividades ao colonizar até mesmo as esferas mais íntimas da vida individual, haveria uma tendência cada vez maior de os excluídos, em sua potência de vida, contrapor os ditames da racionalidade técnica e do chamado capitalismo cultural.

O poder da biopotência ${ }^{2}$ encontraria ressonância, dentre outras atividades humanas, na arte, principalmente na arte contemporânea e na chamada arte relacional. Esta é guiada por um ideal voltado para formas mais fortuitas de habitar o mundo. Diferentemente do ideal moderno, nascido com a

2 O termo biopotência é utilizado no ensaio Poder sobre a vida, potências da vida de Peter Paul Pelbart (2003) em oposição ao termo "biopolítica" forjado por Michael Foucault para designar formas de exercício do poder sobre a vida, em voga desde o século XVIII. Inspirado em Deleuze, o autor conceitua biopotência como o poder da vida, a potência política da vida na medida em que esta subverte os desígnios do poder que incide sobre ela. $\mathrm{O}$ autor chama atenção, no ensaio, para a biopotência da multidão no interior do Império contemporâneo. 
filosofia das luzes e baseado na vontade de emancipação dos indivíduos, no progresso das técnicas e na promessa de instauração de uma sociedade melhor a partir do ideal da razão, a arte relacional "apresenta modelos de universos possíveis", possibilidades de se constituir "modos de existência ou modelos de ação dentro da realidade existente" (Bourriaud, 2009: 18).

A estética relacional emerge em um contexto de nascimento de uma cultura essencialmente urbana em escala mundial e da aplicação do modelo citadino a diversos fenômenos da cultura, o que propiciou uma urbanização da experiência artística, cada vez mais deslocada dos espaços privados para os espaços públicos, possibilitando um diálogo amplo entre o artista e o receptor da obra de arte. Por estar situada nesse contexto, a estética relacional baseia-se então no 'estar-juntos', no encontro entre obra e observador e na produção coletiva de sentidos (Bourriaud, 2009). Desse modo, o viés relacional da arte contemporânea desempenha um papel fundamentalmente político ao transpor sua potência para a esfera das relações humanas.

Nesse contexto, diferentes coletivos surgem no horizonte das grandes cidades com o intuito de ressignificar através dos recursos da arte urbana os espaços até então considerados como meramente funcionais pela racionalidade técnica. Os espaços descontínuos da cidade tornam-se então, a partir da experiência do artístico vivenciada no cotidiano dos passantes, espaços abertos a novas significações baseadas no lúdico e na criatividade. Estes são geradores de afeto e proximidade evocando a outra meia cidade de Sofrônia, isto é, a meia cidade que abriga o circo invade a meia (ou mais que meia) cidade dos bancos de cimento em uma experiência de ressignificação dos espaços impregnados pela lógica da racionalidade técnica. 


\section{A poesia grafada no corpo da cidade: projeções de espaços possíveis}

O grande Khan contempla um império recoberto de cidades que pesam sobre o solo e sobre os homens, apinhado de riquezas e de obstruções, sobrecarregado de ornamentos e de incumbências, complicado por mecanismos e hierarquias, inchado, rijo denso.

'É o seu próprio peso que está esmagando o império', pensa Kublai, e em seus sonhos agora aparecem cidade leves como pipas, cidades esburacadas como rendas, cidades transparentes como mosquiteiros, cidades-fibrade-folha, cidades-linha-da-mão, cidades filigrana que se veem através de sua estrutura opaca e fictícia (Calvino, 1990: 70)

No contexto de produção da arte contemporânea, .diversos coletivos agem nos ambientes do império contemporâneo, visando refletir a respeito da racionalização dos espaços urbanos e buscando relações e modos de experienciar a cidade distintos. Eles nos indicam que é preciso sonhar, fantasiar cidades possíveis, criar utopias de espaços onde sobreviva a troca de experiências e de saberes, a criatividade, o afeto e as relações humanas. A cidade deve produzir subjetividades outras, deve produzir lugares onde sejam 'leves como pipas', 'transparentes como mosquiteiros' no coração do império (Ibdem,1990: 70).

Dentre esses inúmeros coletivos de arte urbana que buscam ressignificar o espaço das cidades, é notória a atuação de artistas oriundos das artes visuais e das artes cênicas, porém pouco tem se produzido na área da literatura e pouco tem se teorizado a respeito. No Brasil, é efetiva a ação de poetas como Maicknuclear e do Coletivo Transverso ${ }^{3}$.

Neste artigo, darei foco a alguns trabalhos do Coletivo Transverso e às possíveis relações entre os poemas de rua produzidos pelo grupo e os espaços das cidades. Formado pelo poeta Cauê Novaes, pela poetiza e atriz Patrícia Del Rey e

\footnotetext{
${ }^{3}$ Vale ressaltar também a ação de anônimos que grafam poemas em sua maioria através de técnicas da pichação nos muros da cidade.
} 
pela artista plástica Patrícia Bagniewski, o coletivo surgiu em 2011 em Brasília e tem trabalhos situados em grandes cidades brasileiras, como Rio de Janeiro e São Paulo. A pesquisa desenvolvida pelo grupo é voltada para intervenções urbanas autorais, a partir do uso de técnicas de stencil, grafite, sticker e performance com a finalidade de refletir sobre as múltiplas possibilidades de socialização e construção de identidade das cidades contemporâneas. A partir de uma estética vinculada a formas poéticas sucintas e imagéticas, como o haikai e os poemas concretistas, os trabalhos do Coletivo buscam ressignificar os espaços da cidade ao olhar dos passantes que a povoam.

Dentre a extensa produção do Coletivo, selecionei um trabalho que exemplifica as características de uma estética voltada para a troca e a relação com o receptor da obra de arte e mais um em que é explorada a linguagem polissêmica da poesia e sua relação com os espaços da cidade. Vale ressaltar que os poemas analisados serão interpretados considerando-se a relação que eles suscitam no ambiente urbano, assim como a capacidade que têm de ressignificar os espaços, tornando-os espaços criativos e lúdicos. Interessa-me o poder desses trabalhos de construir relações de afeto nos espaços da cidade, desenhando um projeto de cidades-sonho, cidadesutopia, "cidades filigrana que se veem através de sua estrutura opaca e fictícia" (Ibdem,1990:70).

\section{A letra como convite ao jogo}

Os espaços educam. Espaços criativos geram pessoas criativas. Nossa paisagem faz parte do que nós somos. A cidade construída a partir de uma lógica funcionalista mecaniza a vida sem deixar espaço para a construção criativa de um imaginário livre. Por monumentos e espaços que sejam instigantes e não que representem uma cultura da militarização e do poder. Por espaços que não oprimam, mas que libertem e estimulem a experiência e a libertação (Poro, 2013: 81).

O trabalho do Coletivo Transverso analisado nessa seção tem como característica principal o convite ao jogo e à experiência de encontro e troca entre artistas entre si e entre o artista e o 
homem comum. Procura-se enxergar nesses trabalhos a experiência de partilha dos espaços urbanos e a ressignificação destes a partir de um uso diferenciado e criativo do patrimônio da cidade, tendo como foco o uso da letra e o estímulo à produção de poesia nos espaços públicos.

A produção poética, no trabalho do Coletivo Transverso, difere bastante das práticas solitárias de leitura (e de produção poética) tão comuns no período da modernidade. O poema, na produção desses artistas, abandona os espaços canônicos do livro para habitar os espaços descontínuos da cidade, e a letra, ao apropriar-se de suportes e técnicas comumente utilizadas nas artes plásticas (como o stencil e o lambe-lambe) ganha em materialidade. A recepção passa então a ser coletiva, pois os poemas invadem o cotidiano dos passantes que habitam a cidade, aproximando-os da vida do homem comum e possibilitando até mesmo uma construção coletiva da obra de arte.

$\mathrm{Na}$ intervenção que se segue do Coletivo Transverso, o lambelambe com a frase "Espaço destinado à poesia" convida o receptor a partilhar dos espaços da cidade de modo lúdico e a apropriar-se desses espaços. A intervenção permite ao homem comum e até mesmo a outros artistas um olhar afetivo direcionado aos espaços meramente funcionalistas que figuram na paisagem das cidades, além de possibilitar a modificação desses espaços na busca de um desenho criativo dos espaços urbanos. Nesse sentido, ressalta-se o caráter coletivo de apropriação da cidade, pois parte-se da premissa de que a cidade é um espaço a ser partilhado e imaginado por todos. A cidade abriga o sonho do artista e do homem comum de uma construção afetiva, criativa e colaborativa de novos espaços e, ao fazer isso, abriga também a noção de uma produção poética coletiva, baseada na relação com o outro, na proximidade e na troca. 

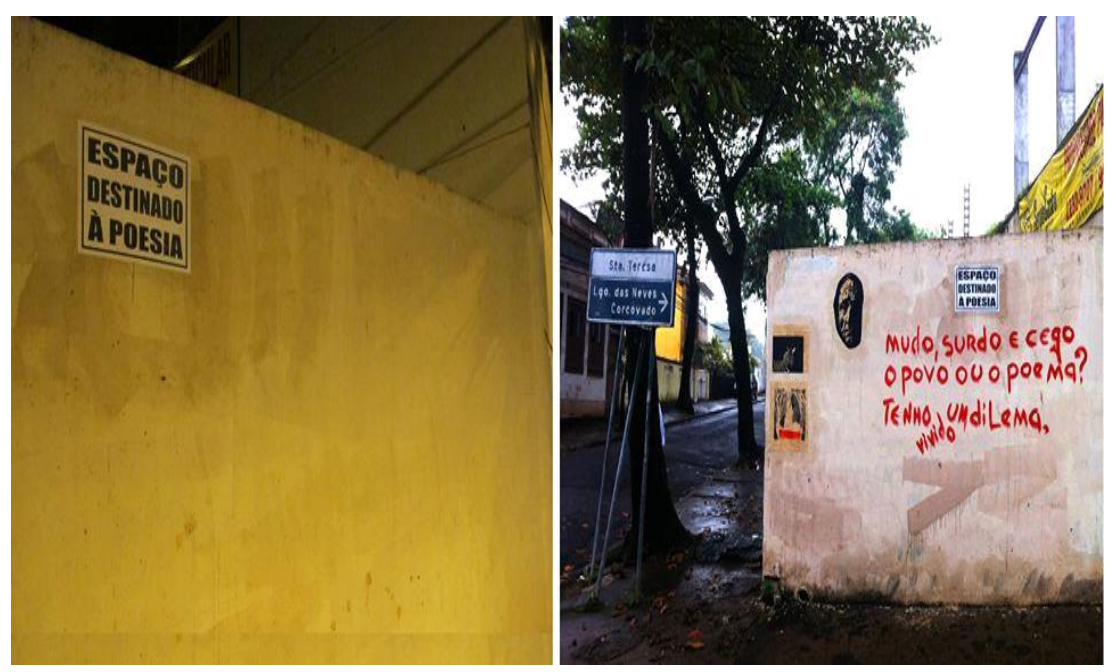

Fig. 1: Intervenção "Espaço destinado à poesia". Coletivo Transverso. Foto Cauê Novaes.

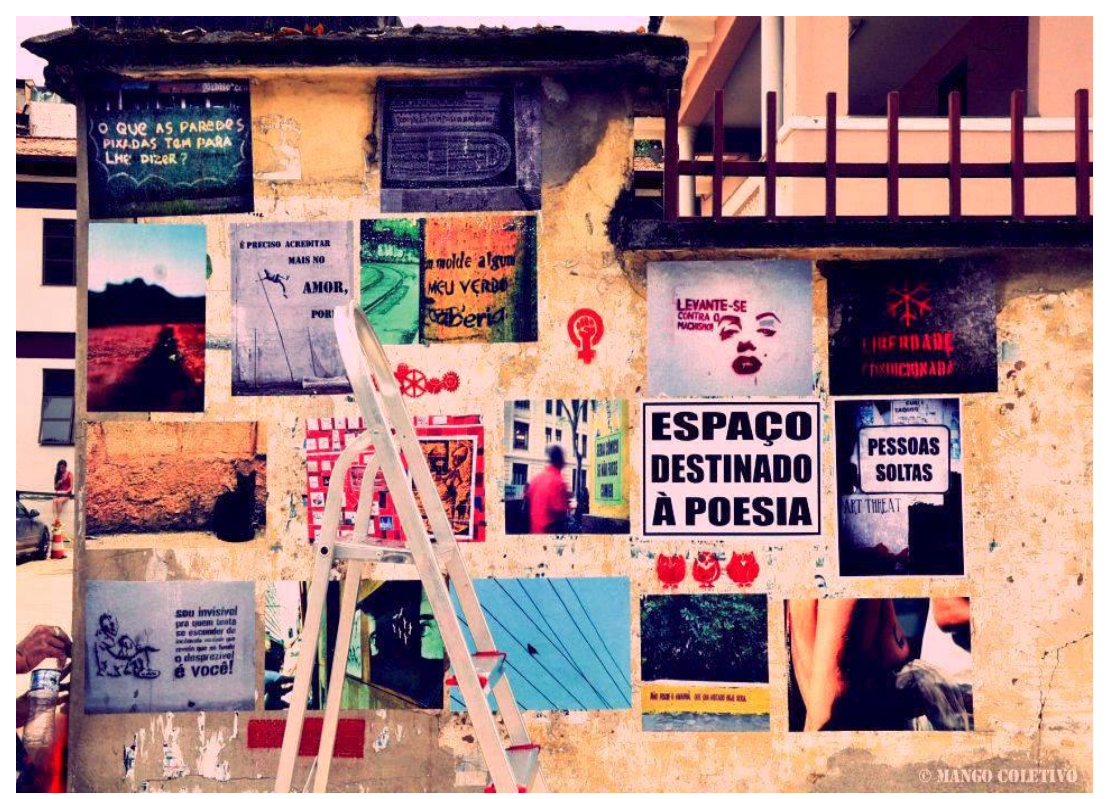

Fig. 2: Intervenção "Espaço destinado à poesia". Coletivo Transverso.

Foto: Cafira Zoé.

Vale ressaltar aqui que, como visto na figura 2, o próprio conceito de poesia é ampliado na visão daqueles que se sentem provocados a participarem da intervenção, já que é notória a presença de imagens poéticas traduzidas pelos recursos das fotografias que compõe o mural. Não tratarei dessa questão neste artigo, mas creio que outros estudos dão 
conta da noção múltipla que se tem de poesia na contemporaneidade e mesmo do imbricamento entre poema e imagem tão presente em trabalhos de arte contemporânea ${ }^{4}$.

Interessa-me discutir aqui a noção do lúdico agregada a esse tipo de construção poética. Johan Huizinga (1999) em Homo Ludens, afirma que enquanto formas da vida social, como a religião e a guerra, foram perdendo sua relação com o jogo ao longo dos séculos, a função do poeta continuaria situada na esfera lúdica de sua origem. A poesia, segundo o autor, situase no mesmo plano visionário que pertence a criança, o animal e o visionário, "na região do sonho, do encantamento, do êxtase, do riso." (Ibdem,1999: 88). O autor chama atenção, desse modo, para distintos aspectos de ludicidade presentes na poesia. O primeiro estaria relacionado a elementos deste tipo específico de linguagem, isto é, a natureza do poema seria lúdica porque este se serve de uma linguagem figurativa. No poema ideia e coisa se unem na imagem, a linguagem poética se difere da linguagem comum, pois enquanto a primeira seria um instrumento prático e útil, a segunda cultivaria as qualidades figurativas e imagéticas da linguagem.

Porém a poesia conservaria também elementos de ludicidade ligados a formas poéticas que atravessaram os séculos, como o enigma e o duelo de versos baseados em perguntas e respostas. Como exemplo de composições poéticas baseadas em perguntas e respostas, Huizinga cita o pantun malaio e 0 hai-kai japonês. O pantun "é uma quadra de rima cruzada, com os dois primeiros versos evocando uma imagem ou expondo um fato, ao qual os dois últimos respondem com uma alusão sutil e por vezes extremamente remota." (Ibdem,1999: 91) Já o hai-kai, segundo o autor, de certo teve em sua origem uma maneira de composição próxima a do pantun malaio,

4 Ver Poéticas do Visível: ensaios sobre a escrita e a imagem, organizado por Márcia Arbex; Diálogos entre linguagens, organizado por Maria do Carmo de Freitas Veneroso e Maria Angélica Melendi e Caligrafias e Escrituras, de Maria do Carmo de Freitas Veneroso. 
configurando-se também como um jogo poético social de perguntas e respostas.

As formas poéticas citadas pelo autor nos são úteis se pensarmos a intervenção literária "Espaço destinado à poesia" como um jogo de "perguntas" e respostas. Nela, os propositores, os poetas do coletivo Transverso, através da frase que dá nome à intervenção, provocam os passantes no cotidiano das cidades a intervirem criativamente nos espaços na forma de uma resposta dada ao chamado estampado no lambe-lambe. O poema como um todo constitui-se então como um emaranhado de vozes tecidas por diferentes atores. Cada um deles é responsável por tecer parte do poema exibido nos muros, que como uma colcha de retalhos, expressa a polifonia de várias vozes até então caladas pela cidade.

\section{O espaço da letra e os epaços "em branco" nas paisagens da cidade}

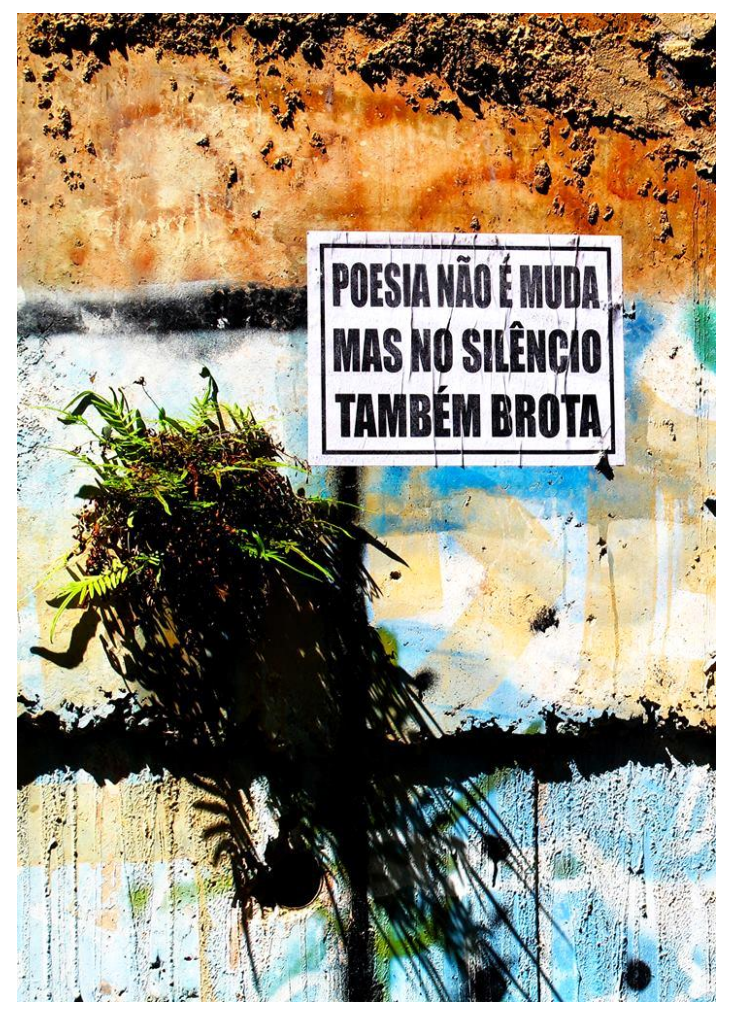

Fig. 3: "Poesia não é muda mas no silêncio também brota". Coletivo Transverso. Foto: Cauê Novaes. 
O poema do coletivo Transverso grafado no corpo do concreto "Poesia não é muda mas no silêncio também brota" conserva a capacidade destacada por Huizinga (1999) do signo poético de metaforizar o mundo. A poesia, atividade lúdica em sua essência, evoca imagens outras das coisas, reinventando a língua e instaurando jogos inusitados na lógica da linguagem convencional. No poema do Coletivo Transverso acima, podese perceber facilmente essa característica da linguagem poética através da polissemia do signo "muda", que no poema tem seu sentido ampliado, conferindo à frase como um todo um potencial imagético. No verso, o fato de a poesia não ser muda remeteria também ao próprio trabalho do coletivo, que busca manter ativa no ambiente das cidades a voz do poema, a voz do poeta e a voz das ruas, porém há também uma referência ao fazer poético que brota do silêncio, da mudez do poeta enquanto ser que contempla o mundo.

O caráter denotativo do signo "muda", no entanto, é realçado pelos elementos trazidos pelo espaço concreto. $O$ verde que brota insistente nas fendas do muro constrói o poema, afirmando a função, também constitutiva do espaço na obra. $O$ poema poderia ser classificado, assim, como uma paisagem poética que brota no horizonte da cidade. Nele, a construção não se dá exclusivamente pela palavra, a estética do espaço, sua diversidade e seu valor semântico são agregados à construção poética, tornando o poema um todo em que letra e cidade dialogam entre si, fundem-se.

Walter Benjamin (1995), em Charles Baudelaire: um lírico no auge do capitalismo, ressalta as ações do flâneur em trânsito pelas ruas da Paris do século XIX. O flâneur desponta como expoente maior daquele que contempla a paisagem citadina $\mathrm{e}$ suas transformações constantes em um contexto em que os ideais modernos se tornam cada vez mais evidentes. Novas paisagens surgem no horizonte dos centros urbanos modernos, e o flâneur, observador atento de todas elas, em intimidade crescente com o ambiente das ruas, traz a cidade para dentro 
do poema. A flânerie do século XIX, respresentada principalmente na obra de Charles Baudelaire, indicaria uma mudança paradigmática na relação entre o poeta e o espaço das cidades ao considerar a rua como o gabinete do poeta e os temas urbanos como centrais na produção literária. Para Benjamin:

assim como a flânerie pode transformar toda a Paris num interior, numa moradia cujos aposentos são os quarteirões, não divididos nitidamente por soleiras como os aposentos de verdade, por outro lado, também, a cidade pode abrir-se diante do transeunte como uma paisagem sem soleiras (Benjamin,1995: 192).

Nos trabalhos do Coletivo Transverso, de modo semelhante, a cidade também é encarada como paisagem que se abre diante dos olhos do poeta, mas torna-se também texto poético. O espaço do texto literário funde-se ao espaço da cidade, tornando o poema um todo em que cidade e texto poético se confundem, se interpenetram. O poeta, como visto nos poemas analisados, considera a cidade e seus moradores como elementos literalmente constitutivos do poema. Os muros e os demais espaços da cidade são vistos a partir de sua carga semântica e juntamente com a voz do homem comum (e de outros artistas da cidade) formam o tecido de um emaranhado de vozes que compõem o texto poético. O poema não é mais limitado pelo espaço da folha, transita livre pelos espaços que constroem a cidade e que o constituem simultaneamente.

Otávio Paz (1976), ao analisar Un coup de dés, de Mallarmé, diria que o maior legado deixado pelo poeta não seria propriamente a palavra que este inaugura, mas o espaço que sua palavra abre. A relação entre a letra e o espaço em branco inaugurada por Mallarmé tiraria o espaço da passividade a qual foi condenado durante séculos pela poesia. Nas palavras de do autor "O espaço torna-se escritura: os espaços em branco (que representam o silêncio, e talvez por isso mesmo) dizem algo que os signos não dizem" (Ibdem,1976: 119). Poder-se-ia, desse modo estabelecer relação entre o legado de Mallarmé e a produção de poéticas do contemporâneo difundida por 
coletivos como o Transverso ao considerar-se a íntima relação entre letra e espaço. O muro e os demais espaços urbanos, nesse contexto, não figuram apenas como meros suportes para os poemas que neles são afixados. Estes espaços significam, atribuem sentido ao poema, sentidos que vão além, inclusive, do efeito estético produzido pela obra. Ao integrar a cidade e a voz de seus moradores ao espaço do poema, além de promover inovações no âmbito estético-formal da poesia contemporânea, o Coletivo recria relações com o espaço no ambiente urbano, desenhando cidades passíveis de afeto, cidades possíveis, cidades que podem ser reinventadas.

\section{Considerações finais}

No capítulo "As cidades Delgadas 4", de As cidades invisíveis, Marco Polo continua descrevendo ao imperador Kublai Khan a cidade de Sofrônia. Uma das meias cidades que compõe Sofrônia é fixa e a outra é provisória, de modo que finda sua temporada, a meia cidade provisória segue viagem em busca de novos territórios. Desse modo, todos os anos chega o dia em que a meia cidade dos bancos, das fábricas e dos palácios é desmontada, desmoronando-se assim os ministérios, os monumentos, as refinarias de petróleo, os hospitais. Fica a Sofrônia das lonas dos circos, dos trenzinhos e das montanhas russas, a meia cidade "pipa", a meia cidade "transparente como mosquiteiro", a meia cidade que povoa os sonhos de Cublai Khan de um império onde impere a leveza (Calvino,1990: 70) .

Esse artigo pretendeu sugerir desenhos, formas e imagens de uma cidade-sonho que já habita timidamente o coração do império contemporâneo. Considera-se a poesia como propulsora de escritas de novas cidades, cidades permeadas pelo afeto, pelo encontro, pela troca de experiências e saberes. Ressalta-se também o potencial de novas formas de escrita e novas possibilidades de suporte e recepção para o texto literário, ao considerar-se o contato entre o texto poético e o ambiente urbano. E identifica-se o potencial dos poemas analisados ao atuarem como contra-racionalidades no coração 
do império, já que, ao ressignificarem os espaços urbanos, propõem escritas de novas cidades menos funcionalistas e mecanizadas e mais passíveis de afeto.

Fica aqui o desejo que a anedota das meias cidades de Sofrônia possa figurar meio às nossas utopias de espaços possíveis, espaços onde prevaleça a brincadeira, a arte e a poesia, e que o poema e as diversas formas do fazer artístico pulsem na vida do coletivo.

\section{Referências}

Benjamin, W. (1995). Charles Baudelaire: um lírico no auge do capitalismo. Tradução [de] José Carlos Martins Baptista et al. São Paulo, SP: Brasiliense.

Bourriaud, N. (2009) Estética relacional. Tradução [de] Denise Bottmann. São Paulo, SP: Martins Fontes.

Calvino, I. (1990). As cidades invisíveis. Tradução [de] Diogo Mainardi. São Paulo, SP: Companhia das Letras.

Coletivo Transverso. (2014, fevereiro 20) Disponível na página: https://www.facebook.com/coletivotransverso?fref=ts.

Hardt, M. \& Negri, A. (2004) Multidão: guerra e democracia na era do império. Tradução [de] Clóvis Marques. Rio de Janeiro, RJ: Record.

Huizinga, J.(1999). Homo ludens: o jogo como elemento da cultura. 4.ed. São Paulo, SP: Perspectiva.

Paz, O. (1976). Signos em Rotação. 2. ed. São Paulo, SP: Perspectiva.

Pelbart, P. (2003) Poder sobre a vida, potências da vida. In: Vida capital: Ensaios de biopolítica. São Paulo, SP: Iluminuras.

Poro, Grupo. (2013, Janeiro - Junho). Manifesto por uma cidade lúdica e coletiva, por uma arte pública, criativa e poética. Revista da Universidade Federal de Minas Gerais, v.20, n.I, p.I-357, 78-89.

Santos, M. (2002). A natureza do espaço: técnica e tempo, razão e emoção. 4. ed. São Paulo, SP: EDUSP. 